\title{
Association of hydrogen peroxide with commercial fungicide formulations in the control of Asian soybean rust
}

\author{
Paulo Henrique Nascimento de Souza ${ }^{1^{*}}$ (1) Lilian Maria Arruda Bacchi ${ }^{1}$ (c) \\ Walber Luiz Gavassoni ${ }^{1}$ (i) Wagner da Paz Andrade ${ }^{1}(\mathbb{B}$
}

${ }^{1}$ Laboratório de Microbiologia e Fitopatologia, Faculdade de Ciências Agrárias, Universidade Federal da Grande Dourados (UFGD), 79825-900, Dourados, MS, Brasil. E-mail: souza.phn.agro@gmail.com. *Corresponding author.

\begin{abstract}
In recent years, there have been reductions in the efficacy of the fungicidal control of Phakopsora pachyrhizi, thereby hindering the management of soybean rust and compromising crop yield. This study evaluated the effects of incorporating hydrogen peroxide ( $\mathrm{H}_{2} \mathrm{O}_{2}$ ) in commercial fungicide formulations on the control of soybean rust. We conducted two experiments, one of which was performed in a greenhouse environment and the other under field conditions. In both environments, we examined the following four control programs using commercial fungicide formulations: (I) azoxystrobin + cyproconazole (quinone outside inhibitor [QoI] + demethylation inhibitor [DMI]); (II) picoxystrobin + cyproconazole (QoI + DMI); (III) pyraclostrobin + epoxiconazole + fluxapyroxad (QoI + DMI + succinate dehydrogenase inhibitor); and (IV) water $\left(\mathrm{H}_{2} \mathrm{O}\right.$ ) (program without fungicide application), combined with the incorporation of (i) $\mathrm{H}_{2} \mathrm{O}_{2}$; (ii) mancozeb (positive control I); (iii) chlorothalonil (positive control II); or (iv) water $\left(\mathrm{H}_{2} \mathrm{O}\right)$ alone. Analyses of infected leaf area and grain yield revealed that the addition of $\mathrm{H}_{2} \mathrm{O}_{2}$ to the formulations of DMI and QoI fungicides led to a reduction in disease severity of between $33 \%$ and $44 \%$ relative to the effects of these products used alone, as well as an increase in yield and SPAD values. The use of $\mathrm{H}_{2} \mathrm{O}_{2}$ and multi-site fungicides alone failed to provide effective control of soybean rust. In addition to enhancing the efficacy of disease control, the use of $\mathrm{H}_{2} \mathrm{O}_{2}$ associated with commercial fungicide mixtures was shown to be a potential tool for the management of fungicide resistance and reduction in losses from Asian soybean rust. Key words: multi-site, oxidant, fungicide resistance, Phakopsora pachyrhizi.
\end{abstract}

Associação de peróxido de hidrogênio com misturas comerciais fungicidas no controle da ferrugem asiática da soja

\begin{abstract}
RESUMO: Nos últimos anos, a eficiência do controle de Phakopsora pachyrhizi por fungicidas tem sido reduzida, dificultando o manejo da ferrugem asiática da soja, o que ocasiona o comprometimento da produtividade. O objetivo deste estudo foi avaliar o efeito da adição do peróxido de hidrogênio $\left(\mathrm{H}_{2} \mathrm{O}_{2}\right)$ em misturas comerciais fungicidas no controle da ferrugem da soja. Foram realizados dois ensaios, um em ambiente de casa de vegetação e outro em condições de campo. Em ambos ambientes foram estudados quatro programas de controle com formulações comerciais: I) azoxistrobina + ciproconazole (IQe + IDM); II) picoxistrobina + ciproconazole (IQe + IDM); III) piraclostrobina + epoxiconazole + fluxapiroxade (IQe + IDM + ISDH); IV) água - $\mathrm{H}_{2} \mathrm{O}$ (sem aplicação fungicida) associados à: i) peróxido de hidrogênio - $\mathrm{H}_{2} \mathrm{O}_{2}$, ii) mancozebe (controle positivo I), iii) clorotalonil (controle positivo II) e iv) água - $\mathrm{H}_{2} \mathrm{O}$ (sem associação). Análises de área foliar lesionada e de rendimento de grãos revelaram que a adição de peróxido de hidrogênio nas misturas de fungicidas IDMs e IQes proporcionou uma redução na severidade da doença entre 33 a 44\% comparado aos produtos isolados, incremento na produtividade e maiores índices SPAD. $\mathrm{O}$ uso isolado do peróxido de hidrogênio e dos fungicidas multissitios não resultou em controle da ferrugem da soja. A utilização do $\mathrm{H}_{2} \mathrm{O}_{2}$ associado a misturas comerciais fungicidas, além de aprimorar a eficiência de controle, demonstra possibilidade de uso como ferramenta para manejo da resistência e redução dos prejuizos provenientes da ferrugem asiática da soja.

Palavras-chave: multissitio, oxidante, resistência a fungicidas, Phakopsora pachyrhizi.
\end{abstract}

\section{INTRODUCTION}

Since the arrival of Asian soybean rust (ASR) in Brazil, fungicides have been widely applied to manage the causal fungus Phakopsora pachyrhizi (Sydow and Sydow). However, over the course of 18 harvests, there have been reports of yield losses of between $30 \%$ and $100 \%$ reductions in the efficacy of disease control. The emergence of isolates resistant to the main fungicide groups used in management programs [demethylation inhibitors (DMIs), quinone outside inhibitors (QoIs), and succinate 
dehydrogenase inhibitors (SDHIs)] has been observed (SCHMITZ et al., 2014; KLOSOWSKI et al., 2016; FRAC, 2017).

Most fungicides registered for the control ASR are site specific, acting at single sites in pathogen metabolic pathways. However, the successive application of these products, divergence from the recommended doses, and curative application combined with the high adaptability of the fungus have contributed to the selection and increase of resistant populations, thereby substantially hampering effective disease management (ISHII \& HOLLOMON, 2015; REIS et al., 2019).

Given the destructive potential of the disease and the resistance of the fungus $P$. pachyrhizi to fungicides, the need for studies on antiresistance management and extension of the useful life of fungicide formulations has been highlighted. Among the approaches that seek to curtail resistance development is the combination of commercial fungicide mixtures with compounds that act by interfering with vital metabolic processes of the fungal cell, as in the case of studies on the association of multisite fungicides such as mancozeb, chlorothalonil, and copper fungicides (BALARDIN et al., 2017; REIS et al., 2019; ZUNTINI et al., 2019). In this regard, within the literature on organic production, there are reports of hydrogen peroxide $\left(\mathrm{H}_{2} \mathrm{O}_{2}\right)$, a low-cost compound, being used in the disinfection of fruits and vegetables with effective control of fungi such as Eutypa lata, Fusarium circinatum, Stagonosporopsis citrulli, and Pyricularia oryzae (AVER'YANOV et al., 2007; KEINATH \& DUBOSE, 2017; SOSNOWSKI et al., 2013; VAN WYK et al., 2012). The disinfectant properties of $\mathrm{H}_{2} \mathrm{O}_{2}$ are attributed to its oxidative capacity, which contributed to the degradation of lipid membranes, DNA, and other vital components of fungal cells (LINLEY et al., 2012; MATTOS et al., 2003).

Considering the multiple properties of $\mathrm{H}_{2} \mathrm{O}_{2}$ (LINLEY et al., 2012), its use in the integrated management of soybean rust control has been proposed, with the aim of reducing selection pressure and enhancing the efficacy of site-specific fungicides. To date, however, there have been no studies reporting its use in the cultivation of soybean, nor, to the best of our knowledge, are there any data regarding the efficacy of its association with the currently applied commercial fungicide formulations.

In this context, this study evaluated the effect of the association of $\mathrm{H}_{2} \mathrm{O}_{2}$ with commercial fungicide formulations on the control of the fungus $P$. pachyrhizi and on soybean crop yield.

\section{MATERIALS AND METHODS}

The present study involved two parallel experiments, one of which was performed in a greenhouse and the other under field conditions. In both environments, we examined the efficacy of four management programs for the control of soybean rust: (I) Priori Xtra ${ }^{\circledR}$ [azoxystrobin + cyproconazole: QoI + DMI (60+24 g a.i./ha)] + Nimbus $0.5 \%$ v/v;(II) Aproach Prima ${ }^{\circledR}$ [picoxystrobin + cyproconazole: QoI + DMI $(60+24$ g a.i./ha) + Nimbus $0.75 \%$ v/v;(III) Ativum ${ }^{\circledR}$ [pyraclostrobin + epoxiconazole + fluxapyroxad: QoI + DMI + SDHI $(50+50+81 \mathrm{~g}$ a.i./ha) + Assist $0.5 \mathrm{v} / \mathrm{v}$; and (IV) without fungicide $\left(\mathrm{H}_{2} \mathrm{O}\right)$, combined with one of four additions to the application solution, (i) MOB Reforce ${ }^{\circledR}\left[\mathrm{H}_{2} \mathrm{O}_{2}\right.$ (18 g a.i./ha)]; (ii) positive control I: Unizeb Gold ${ }^{\circledR}$ [mancozeb (1500 g a.i./ha)]; (iii) positive control II: Bravonil $^{\circledR}$ [chlorothalonil (1296 g a.i./ha)]; and (iv) no addition $\left(\mathrm{H}_{2} \mathrm{O}\right)$.

\section{Experiment I - Greenhouse}

Seeds of the soybean cultivar Monsoy 6410 were sown in plastic pots containing $5 \mathrm{~kg}$ of a mixture of clay soil, sand, and substrate (1:1:1). The experimental unit consisted of two plants per pot arranged in a $4 \times 4$ factorial design, with four ASR control programs combined with four additions to the application solution $\left(\mathrm{H}_{2} \mathrm{O}_{2}\right.$, chlorothalonil, mancozeb, and no addition), in a randomized block design with six repetitions.

The fungicides were applied to plants at the V4 stage of growth (FEHR \& CAVINESS, 1977) using a $\mathrm{CO}_{2}$-pressurized pump sprayer $(350 \mathrm{~mL})$, with approximately $10 \mathrm{~mL}$ being applied per pot. As an inoculum, urediniospores of the fungus P. pachyrhizi were collected and suspended in distilled water containing. Tween 20 dispersant $(0.1 \mathrm{~mL}$ per liter of water), and a suspension of $5 \times 10^{5}$ urediniospores per $\mathrm{mL}$ was sprayed onto the plants at 4,8 , and 12 days after fungicide treatment.

The misting system of the greenhouse was activated at $3 \mathrm{~h}$ intervals, dispensing fine clouds of water over $5 \mathrm{~min}$ periods from 18:00 to 06:00, thereby ensuring the presence of free water on the leaves required for initiating the infection process. The temperature of the greenhouse throughout the evaluation period ranged between $19^{\circ} \mathrm{C}$ and $30^{\circ} \mathrm{C}$.

During the evaluations performed at 21 and 35 days after fungicide application (DAF), the chlorophyll index of the soybean foliage was quantified using a SPAD-502 meter (Konica Minolta) in the central leaflet of the third fully 
open trifoliate leaf from the apex to the base of the plant (YOKOYAMA et al., 2018). The number of $P$. pachyrhizi uredia was determined at $35 \mathrm{DAF}$ in eight leaflets per plot by direct counting using a stereoscopic microscope $(\times 10)$, and the percentage of leaf area infected was determined in all leaflets according to the diagrammatic scale proposed by GODOY et al. (2006).

\section{Experiment II - In the field}

The field experiment was conducted at the experimental farm of the Faculty of Agricultural Sciences (FAECA) of the Federal University of Grande Dourados (UFGD) in the city of Dourados - MS, located at $22^{\circ} 13^{\prime} 52.45^{\prime \prime} \mathrm{S}$ latitude and $54^{\circ} 59^{\prime \prime} 10.54^{\prime \prime} \mathrm{W}$ longitude. The experimental design was randomized blocks, consisting of 16 treatments in a split-plot arrangement with six repetitions. The main plots were the treatments of two sowing seasons (November 15 and December 10), the subplots were the standard programs used to control ASR, and the sub-subplots were the four formulations in association with the standard programs $\left(\mathrm{H}_{2} \mathrm{O}_{2}\right.$, chlorothalonil, mancozeb, no association).

The experimental units comprised six 6-m-long soybean rows spaced at $0.45 \mathrm{~m}\left(16.2 \mathrm{~m}^{2}\right)$. The four central rows extending to within $1 \mathrm{~m}$ of the plot edge were used in the evaluations, totaling $7.2 \mathrm{~m}^{2}$ of usable area.

Fungicides were applied using a $\mathrm{CO}_{2}$ pressurized knapsack sprayer equipped with six Magno 110.02 nozzles, spaced $0.50 \mathrm{~m}$ apart, operating at a pressure of 40 PSI with the volume of solution being adjusted to $150 \mathrm{~L} / \mathrm{ha}$. During the evaluation period, plants received three applications, the first at the beginning of flowering, and the second and third at 21 and 35 days after the initial application.

To evaluate the severity of Asiatic rust, six collections of 20 leaflets from the lower and middle third of the plants were performed weekly, commencing 14 days after the initial application, at which time the number of fungal uredia and percentage of leaf area infected by the pathogen were determined. The area under the progress curve (AUPC) of the uredia and that of the percentage of infected leaf were estimated using the equation proposed by CAMPBELL \& MADDEN (1990). In both sowing seasons, crop defoliation was assessed visually in the field at the $\mathrm{R}_{6}$ stage, according to the scale proposed by HIRANO et al. (2010).

During the first and second seasons, plants growing in the defined useful area were collected by hand on March 13, 2019 and March 25, 2019, respectively. For each plot, the mean grain mass was determined, corrected to a moisture content of $13 \%$, and expressed in terms of $\mathrm{kg} / \mathrm{ha}$.

The data were subjected to residual analysis, the SHAPIRO \& WILK (1965) test to assess data normality, and analysis of variance using SAS statistical software version 9.4. When there were significant differences between the means of the treatments, comparisons were made using the Tukey test at $1 \%$ and $5 \%$ probability levels.

\section{RESULTS AND DISCUSSION}

\section{Experiment I - Greenhouse}

We reported an interactive effect between the commercial formulations and the evaluated associations on the SPAD index and number of $P$. pachyrhizi uredia. In the evaluations performed at 21 and $35 \mathrm{DAF}$, it was reported that with the exception of the treatment with the commercial triple fungicide mixture, the addition of $\mathrm{H}_{2} \mathrm{O}_{2}$ resulted in higher SPAD values than those obtained in the ASR control programs without its addition and were similar to the means obtained with the association of multi-site fungicides (Table 1).

In the control programs involving the fungicide azoxystrobin + cyproconazole, there was a reduction in the number of uredia when $\mathrm{H}_{2} \mathrm{O}_{2}$ was added (Table 2) and the control efficacy was similar to that obtained in the association with mancozeb and chlorothalonil. However, we observed no comparable reductions in the number of lesions in the treatments in which $\mathrm{H}_{2} \mathrm{O}_{2}$, mancozeb or chlorothalonil were applied alone.

In other pathosystems, AVER'YANOV et al. (2007), who evaluated the in vitro effects of $\mathrm{H}_{2} \mathrm{O}_{2}$ concentration on the germination of Pyricularia grisea spores, observed the complete inhibition of the fungus at concentrations of $\mathrm{H}_{2} \mathrm{O}_{2}$ between $10^{-5}$ and $10^{-6} \mathrm{M}$. KANETIS et al. (2008), have reported that the efficacy of the fungicides azoxystrobin, fludioxonil, thiabendazole, and pyrimethanilin control of the conidial germination of Penicillium digitatum increased with the addition of $\mathrm{H}_{2} \mathrm{O}_{2}$. Moreover, these authors reported that there were no adverse effects regarding the compatibility and stability of fungicide solutions in the assessed treatments.

Although, we observed no evidence of fungal control in response to the use of $\mathrm{H}_{2} \mathrm{O}_{2}$ or the multi-site fungicides alone, the values of SPAD in the treatments with $\mathrm{H}_{2} \mathrm{O}_{2}$ were found to be higher than those obtained in the treatments without it, which tends to indicate a secondary benefit, i.e., protection 
Table 1 - Means of the SPAD index of soybean Monsoy 6410 at 21 and 35 days after application (DAF) of commercial fungicide formulations associated with multi-site fungicides or hydrogen peroxide in a greenhouse.

\begin{tabular}{|c|c|c|c|c|c|c|c|c|}
\hline \multirow[t]{2}{*}{ Standard formulation } & \multicolumn{8}{|c|}{ 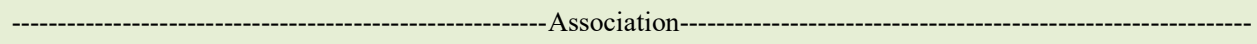 } \\
\hline & \multicolumn{2}{|c|}{----------- $\mathrm{H}_{2} \mathrm{O}------------$} & \multicolumn{2}{|c|}{--------CLTN--------- } & \multicolumn{2}{|c|}{--------------MZB----------- } & \multicolumn{2}{|c|}{--------- $\mathrm{H}_{2} \mathrm{O}_{2}$} \\
\hline \multicolumn{9}{|c|}{ - } \\
\hline $\mathrm{H}_{2} \mathrm{O}$ & 24.8 & $\mathrm{C} \mathrm{c}$ & 28.7 & $\mathrm{C} \mathrm{b}$ & 32.1 & $\mathrm{~B}$ a & 28.9 & $\mathrm{C} b$ \\
\hline $\mathrm{AZ}+\mathrm{CP}$ & 25.5 & $\mathrm{C} \mathrm{b}$ & 32.1 & $\mathrm{~B}$ a & 32.9 & $\mathrm{~B}$ a & 31.2 & $\mathrm{BCa}$ \\
\hline $\mathrm{PC}+\mathrm{CP}$ & 30.3 & $\mathrm{~B} \mathrm{c}$ & 31.8 & $\mathrm{~B} \mathrm{bc}$ & 34.4 & $\mathrm{ABa}$ & 32.9 & $\mathrm{~B} a b$ \\
\hline $\mathrm{PT}+\mathrm{EX}+\mathrm{FX}$ & 35.3 & A a & 34.6 & A a & 35.6 & $\mathrm{~A}$ a & 35.8 & $\mathrm{~A} \mathrm{a}$ \\
\hline \multicolumn{9}{|c|}{ 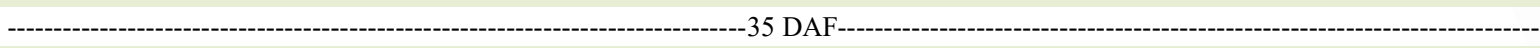 } \\
\hline $\mathrm{H}_{2} \mathrm{O}$ & 11.7 & $\mathrm{C} \mathrm{c}$ & 15.4 & $\mathrm{C} \mathrm{b}$ & 20.5 & $\mathrm{C}$ a & 17.8 & $\mathrm{C} \mathrm{ab}$ \\
\hline $\mathrm{AZ}+\mathrm{CP}$ & 15.5 & $\mathrm{~B} b$ & 21.6 & $\mathrm{~B}$ a & 23.6 & $\mathrm{~B}$ a & 22.3 & $\mathrm{~B}$ a \\
\hline $\mathrm{PC}+\mathrm{CP}$ & 17.8 & $\mathrm{~B} \mathrm{~b}$ & 22.96 & $\mathrm{~B}$ a & 25.8 & $\mathrm{~B}$ a & 24.1 & $\mathrm{~B}$ a \\
\hline $\mathrm{PT}+\mathrm{EX}+\mathrm{FX}$ & 28.3 & A a & 28.23 & A a & 29.6 & A a & 30.0 & A a \\
\hline \multicolumn{9}{|c|}{--------------------CV(\%) 21 DAF:-------------------- } \\
\hline \multicolumn{3}{|c|}{-------------------CV (\%) 35 DAF:------------------ } & & & & 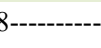 & & \\
\hline
\end{tabular}

Key: $\mathrm{H}_{2} \mathrm{O}$ : water; $\mathrm{AZ}+\mathrm{CP}$ : azoxystrobin + cyproconazole; $\mathrm{PC}+\mathrm{CP}$ : picoxystrobin + cyproconazole; $\mathrm{PT}+\mathrm{EX}+\mathrm{FX}:$ pyraclostrobin + epoxiconazole + fluxapyroxad; $\mathrm{H}_{2} \mathrm{O}_{2}$ : hydrogen peroxide; CLTN: chlorothalonil; MZB: mancozeb. Means followed by the same uppercase letter in columns and lowercase letter in rows do not differ significantly, as determined using the Tukey test $(\mathrm{P}<0.01)$.

from chlorophyll degradation. ALVES \& JULIATTI (2018), who investigated the physiological processes involved in the association of the protective fungicide mancozeb with site-specific formulations, reported that even in the absence of disease control, association of the applied fungicides had the effect of increasing the AUPC for chlorophyll concentration and levels of water-use efficiency. The authors attributed these responses to mechanisms associated with protection of the photosynthetic apparatus provided by some fungicide groups, particularly with respect to more efficient preservation of chlorophyll $b$.

\section{Experiment II - In the field}

Analysis of variance revealed a threeway interaction between the factors standard formulation, association, and sowing season for the analyzed variables, with the exception of percentage

Table 2 - Number of Phakopsora pachyrhizi uredia in soybean Monsoy 6410 at 35 days after application (DAF) of commercial fungicide formulations associated with multi-site fungicides or hydrogen peroxide in a greenhouse.

\begin{tabular}{|c|c|c|c|c|c|c|c|c|c|}
\hline \multirow{3}{*}{$\begin{array}{l}\text { Standard formulation } \\
\mathrm{H}_{2} \mathrm{O}\end{array}$} & \multicolumn{9}{|c|}{---1 } \\
\hline & \multicolumn{2}{|c|}{ 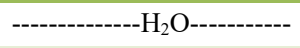 } & \multicolumn{3}{|c|}{-------------CLTN----------- } & \multicolumn{2}{|c|}{---------------MZB----------- } & \multicolumn{2}{|c|}{--------- $\mathrm{H}_{2} \mathrm{O}_{2}$} \\
\hline & 31.23 & A a & 27.11 & A & a & 23.49 & A a & 29.43 & A a \\
\hline $\mathrm{AZ}+\mathrm{CP}$ & 27.43 & A a & 12.05 & B & $\mathrm{b}$ & 4.27 & $\mathrm{~B} \mathrm{c}$ & 6.94 & $\mathrm{BCbc}$ \\
\hline $\mathrm{PC}+\mathrm{CP}$ & 21.88 & $\mathrm{~A}$ a & 10.67 & B & $\mathrm{b}$ & 6.23 & $\mathrm{~B} b$ & 13.38 & $\mathrm{~B}$ ab \\
\hline $\mathrm{PT}+\mathrm{EX}+\mathrm{FX}$ & 5.73 & $\mathrm{~B}$ a & 6.38 & B & $\mathrm{a}$ & 2.67 & $\mathrm{~B}$ a & 6.04 & $\mathrm{C}$ a \\
\hline
\end{tabular}

Key: $\mathrm{H}_{2} \mathrm{O}$ : water; $\mathrm{AZ}+\mathrm{CP}$ : azoxystrobin + cyproconazole; $\mathrm{PC}+\mathrm{CP}$ : picoxystrobin + cyproconazole; $\mathrm{PT}+\mathrm{EX}+\mathrm{FX}$ : pyraclostrobin + epoxiconazole + fluxapyroxad; $\mathrm{H}_{2} \mathrm{O}_{2}$ : hydrogen peroxide; CLTN: chlorothalonil; MZB: mancozeb. Means followed by the same uppercase letter in columns and lowercase letter in rows do not differ significantly, as determined using the Tukey test $(\mathrm{P}<0.01)$. Data for the number of lesions were transformed using $\sqrt{ } x+0.5$. 
of defoliation, for which an interaction was only observed between commercial formulations and the assessed associations.

$\mathrm{H}_{2} \mathrm{O}_{2}$ combined with the formulations azoxystrobin + cyproconazole and picoxystrobin + cyproconazole reduced the AUPC of uredia during both the first and second seasons by mean values of $39.32 \%$ and $43.94 \%$, respectively (Table 3 ). In both seasons, the addition of $\mathrm{H}_{2} \mathrm{O}_{2}$ resulted in an ASR control gain relative to the treatment without associated formulations, and efficacy was observed to be similar to that obtained from the association with the protective fungicide chlorothalonil.

With regards to the AUPC of leaf area infected by P. pachyrhizi, we reported that the addition of $\mathrm{H}_{2} \mathrm{O}_{2}$ to the control programs in the first season had a significant effect only when associated with the fungicide azoxystrobin + cyproconazole, with a mean reduction of $30.65 \%$. In the second season, the effect was observed for the two fungicides, with QoI + DMI formulations azoxystrobin + cyproconazole and picoxystrobin + cyproconazole resulting in a $42.67 \%$ reduction in infected leaf area (Table 4). The difference between the two seasons is probably related to the higher severity of the disease in the late season and with the intrinsic differences in efficacy between the fungicides used in the control programs.
In both seasons, the analysis of severity indicated no significant effects of the application of $\mathrm{H}_{2} \mathrm{O}_{2}$, mancozeb, or chlorothalonil alone, or in associations with pyraclostrobin + epoxiconazole + fluxapyroxad. The first case may be associated with the low systemicity of these formulations, the protective effect of which is limited to the plant surface. In this regard, ALVES \& JULIATTI (2018) reported that products with this characteristic required a greater number of applications and a shorter time interval between applications than those recommended for mixed formulations. The second case can be explained by the efficacy of triple formulation, which provided better control rates, regardless of the combination used.

With regards to percentage defoliation, we detected no significant difference between the use of $\mathrm{H}_{2} \mathrm{O}_{2}$ and multi-site fungicides applied in association with QoI + DMI fungicides (Table 5). Compared with the standard control programs (commercial formulations applied alone), these associations resulted in a $42 \%-68 \%$ reduction in percentage defoliation.

In our analysis of yields obtained in treatments assessing interactions between the control programs and the associations within each experimental season (Table 6), we reported that the addition of $\mathrm{H}_{2} \mathrm{O}_{2}$ to fungicides based on QoIs + DMIs

Table 3 - Area under the progress curve (AUPC) for the number of uredia of Phakopsora pachyrhizi on soybean Monsoy 6410 (2018/19 crops) subjected to the application of commercial fungicide formulations associated with multi-site fungicides or hydrogen peroxide.

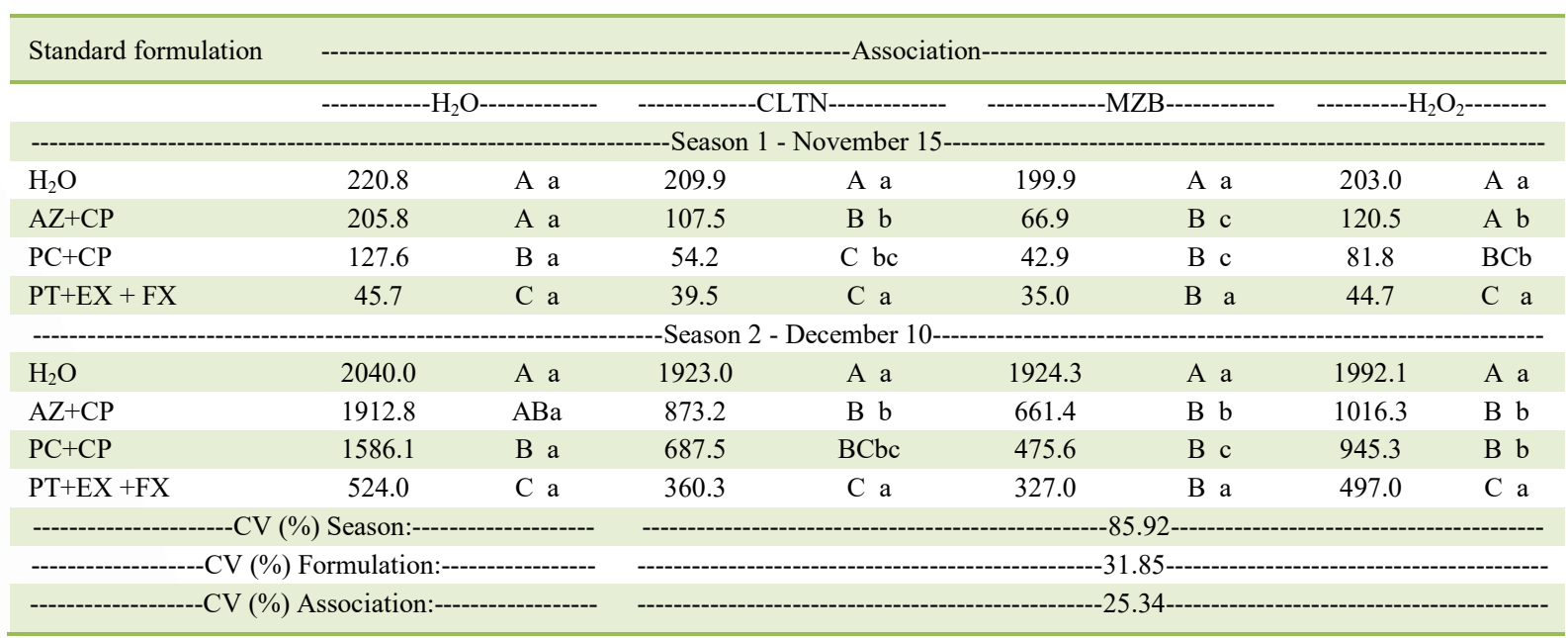

Key: $\mathrm{H}_{2} \mathrm{O}$ : water; $\mathrm{AZ}+\mathrm{CP}$ : azoxystrobin + cyproconazole; $\mathrm{PC}+\mathrm{CP}$ : picoxystrobin + cyproconazole; $\mathrm{PT}+\mathrm{EX}+\mathrm{FX}$ : pyraclostrobin + epoxiconazole + fluxapyroxad; $\mathrm{H}_{2} \mathrm{O}_{2}$ : hydrogen peroxide; CLTN: chlorothalonil; MZB: mancozeb. Means followed by the same uppercase letter in columns and lowercase letter in rows do not differ significantly, as determined using the Tukey test (P $<0.01)$.

Ciência Rural, v.52, n.3, 2022. 
Table 4 - Area under the progress curve (AUPC) for leaf area infected by Phakopsora pachyrhizi in Monsoy 6410 soybean (2018/19 crops) subjected to the application of commercial fungicide formulations associated with multi-site fungicides or hydrogen peroxide.

\begin{tabular}{|c|c|c|c|c|c|c|c|c|}
\hline \multirow[t]{2}{*}{ Standard formulation } & \multicolumn{8}{|c|}{ 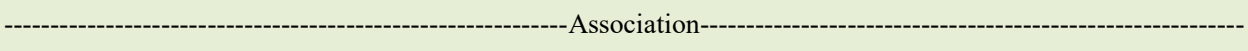 } \\
\hline & \multicolumn{2}{|c|}{------------ $\mathrm{H}_{2} \mathrm{O}---\cdot--------$} & \multicolumn{2}{|c|}{-------------CLTN----------- } & \multicolumn{2}{|c|}{-------------MZB--------- } & \multicolumn{2}{|c|}{ 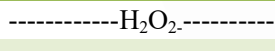 } \\
\hline \multicolumn{9}{|c|}{ 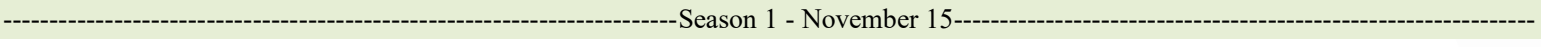 } \\
\hline $\mathrm{H}_{2} \mathrm{O}$ & 186.5 & A a & 139.0 & A a & 160.7 & A a & 154.3 & A a \\
\hline $\mathrm{AZ}+\mathrm{CP}$ & 165.1 & A a & 98.7 & $\mathrm{ABb}$ & 58.1 & $\mathrm{~B} \mathrm{~b}$ & 107.0 & $\mathrm{ABb}$ \\
\hline $\mathrm{PC}+\mathrm{CP}$ & 136.0 & A a & 76.0 & $\mathrm{~B} \quad \mathrm{~b}$ & 52.0 & $\mathrm{~B} \mathrm{~b}$ & 98.0 & $\mathrm{BCab}$ \\
\hline $\mathrm{PT}+\mathrm{EX}+\mathrm{FX}$ & 50.4 & $\mathrm{~B}$ a & 61.6 & B a & 41.6 & $\mathrm{~B}$ a & 49.9 & $\mathrm{C}$ a \\
\hline \multicolumn{9}{|c|}{ - } \\
\hline $\mathrm{H}_{2} \mathrm{O}$ & 771.1 & A a & 695.0 & A a & 729.5 & A a & 742.3 & A a \\
\hline $\mathrm{AZ}+\mathrm{CP}$ & 697.6 & $\mathrm{ABa}$ & 326.6 & $\mathrm{~B}$ bc & 281.6 & $\mathrm{~B} \mathrm{c}$ & 415.1 & $\mathrm{~B} \mathrm{~b}$ \\
\hline $\mathrm{PC}+\mathrm{CP}$ & 592.3 & B a & 312.2 & $\mathrm{~B}$ bc & 194.9 & $\mathrm{BCc}$ & 436.0 & $\mathrm{~B} \mathrm{~b}$ \\
\hline $\mathrm{PT}+\mathrm{EX}+\mathrm{FX}$ & 255.1 & $\mathrm{C}$ a & 168.0 & $\mathrm{C}$ a & 136.5 & $\mathrm{C}$ a & 223.9 & $\mathrm{C}$ a \\
\hline \multicolumn{3}{|c|}{ 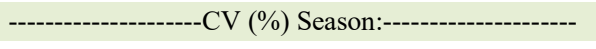 } & \multicolumn{6}{|c|}{ - } \\
\hline \multicolumn{3}{|c|}{ 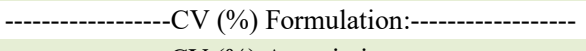 } & \multirow{2}{*}{\multicolumn{6}{|c|}{ 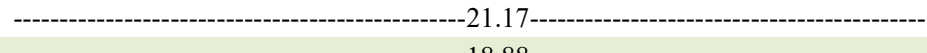 }} \\
\hline - & ssociation: & ---------- & & & & & & \\
\hline
\end{tabular}

Key: $\mathrm{H}_{2} \mathrm{O}$ : water; $\mathrm{AZ}+\mathrm{CP}$ : azoxystrobin + cyproconazole; $\mathrm{PC}+\mathrm{CP}$ : picoxystrobin + cyproconazole; PT $+\mathrm{EX}+\mathrm{FX}:$ pyraclostrobin + epoxiconazole + fluxapyroxad; $\mathrm{H}_{2} \mathrm{O}_{2}$ : hydrogen peroxide; CLTN: chlorothalonil; MZB: mancozeb. Means followed by the same uppercase letter in columns and lowercase letter in rows do not differ significantly, as determined using the Tukey test (P $<0.01)$.

resulted in average yield increases of 132.6 and 243.1 $\mathrm{kg} / \mathrm{ha}$ for the first and second seasons, respectively.

The association of the control program based on the triple formulation (pyraclostrobin + epoxiconazole + fluxapyroxad) with both $\mathrm{H}_{2} \mathrm{O}_{2}$ and the multi-site fungicides mancozeb and chlorothalonil resulted in increased yields in the second sowing season. This finding indicated that there are other benefits of the association with multi-site fungicides in addition to the direct action on fungal cells, given that during the course of all experiments, we detected no evidence to indicate a gain in control for any of the associations with the triple formulation. The potential additional benefits obtained with the application of $\mathrm{H}_{2} \mathrm{O}_{2}$ reported in the literature are as follows: induction of the antioxidant defense systems of plants,; thereby, reducing the effects of salt stress (CARVALHO et al., 2011); an increase

Table 5 - Percentage defoliation (\%) of soybean Monsoy 6410(2018/19 crops), at the R6 stage, subjected to the application of commercial fungicide formulations associated with multi-site fungicides or hydrogen peroxide.

\begin{tabular}{|c|c|c|c|c|c|c|c|c|c|}
\hline \multirow{3}{*}{$\begin{array}{l}\text { Standard formulation } \\
\mathrm{H}_{2} \mathrm{O}\end{array}$} & \multicolumn{9}{|c|}{------------------------------------------------------------Association----------------------------------------------------------- } \\
\hline & \multicolumn{2}{|c|}{ 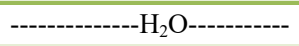 } & \multicolumn{3}{|c|}{-------------CLTN----------- } & \multicolumn{2}{|c|}{---------------MZB----------- } & \multicolumn{2}{|c|}{----------- $\mathrm{H}_{2} \mathrm{O}_{2}--------$} \\
\hline & 40.00 & A a & 37.50 & A & & 32.50 & A a & 36.25 & A a \\
\hline $\mathrm{AZ}+\mathrm{CP}$ & 35.00 & $\mathrm{ABa}$ & 11.25 & B & $\mathrm{b}$ & 12.50 & $\mathrm{~B} \mathrm{~b}$ & 15.00 & $\mathrm{~B} \mathrm{~b}$ \\
\hline $\mathrm{PC}+\mathrm{CP}$ & 26.25 & $\mathrm{~B}$ a & 11.25 & B & $\mathrm{b}$ & 10.00 & $\mathrm{~B} \mathrm{~b}$ & 15.00 & $\mathrm{~B} \mathrm{~b}$ \\
\hline $\mathrm{PT}+\mathrm{EX}+\mathrm{FX}$ & 11.25 & $\mathrm{C} \mathrm{a}$ & 7.50 & B & $\mathrm{a}$ & 7.50 & $\mathrm{~B}$ a & 8.75 & $\mathrm{~B}$ a \\
\hline
\end{tabular}

Key: $\mathrm{H}_{2} \mathrm{O}$ : water; $\mathrm{AZ}+\mathrm{CP}$ : azoxystrobin + cyproconazole; $\mathrm{PC}+\mathrm{CP}$ : picoxystrobin + cyproconazole; $\mathrm{PT}+\mathrm{EX}+\mathrm{FX}:$ pyraclostrobin + epoxiconazole + fluxapyroxad; $\mathrm{H}_{2} \mathrm{O}_{2}$ : hydrogen peroxide; CLTN: chlorothalonil; MZB: mancozeb. Means followed by the same uppercase letter in columns and lowercase letter in rows do not differ significantly, as determined using the Tukey test (P $<0.01)$. 
Table 6 - Yield (kg/ha) of soybean Monsoy 6410 (2018/19 crops), subjected to the application of commercial fungicide formulations associated with multi-site fungicides or hydrogen peroxide.

\begin{tabular}{|c|c|c|c|c|c|c|c|c|}
\hline \multirow[t]{2}{*}{ Standard formulation } & \multicolumn{8}{|c|}{ 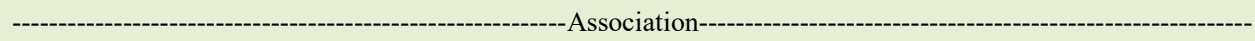 } \\
\hline & \multicolumn{2}{|c|}{-------------H $\mathrm{H}_{2} \mathrm{O}------------$} & \multicolumn{2}{|c|}{-------------CLTN---------- } & \multicolumn{2}{|c|}{---------------MZB------------ } & \multicolumn{2}{|c|}{--------- $\mathrm{H}_{2} \mathrm{O}_{2}--------$} \\
\hline \multicolumn{9}{|c|}{ - } \\
\hline $\mathrm{H}_{2} \mathrm{O}$ & 2366.0 & $\mathrm{~B}$ a & 2380.5 & $\mathrm{~B}$ a & 2445.4 & $\mathrm{~B}$ a & 2366.3 & $\mathrm{~B}$ a \\
\hline $\mathrm{AZ}+\mathrm{CP}$ & 2427.2 & $\mathrm{~B} \mathrm{c}$ & 2628.0 & A $a b$ & 2693.7 & A a & 2539.9 & $\mathrm{Ab}$ \\
\hline $\mathrm{PC}+\mathrm{CP}$ & 2443.6 & $\mathrm{~B} \mathrm{~b}$ & 2633.6 & A a & 2702.7 & A a & 2596.2 & $\mathrm{~A} \mathrm{a}$ \\
\hline $\mathrm{PT}+\mathrm{EX}+\mathrm{FX}$ & 2644.7 & A a & 2685.8 & A a & 2691.2 & A a & 2648.0 & A a \\
\hline \multicolumn{9}{|c|}{ 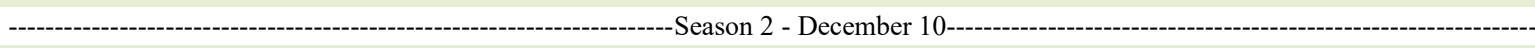 } \\
\hline $\mathrm{H}_{2} \mathrm{O}$ & 1182.8 & $\mathrm{C}$ a & 1127.7 & $\mathrm{C}$ a & 1177.8 & $\mathrm{~B}$ a & 1154,6 & $\mathrm{C}$ a \\
\hline $\mathrm{AZ}+\mathrm{CP}$ & 1188.0 & $\mathrm{C} \mathrm{c}$ & 1654.6 & $\mathrm{~B} b$ & 1910.2 & A a & 1495.2 & $\mathrm{~B} \mathrm{~b}$ \\
\hline $\mathrm{PC}+\mathrm{CP}$ & 1341.4 & $\mathrm{~B} \mathrm{c}$ & 1726.6 & $\mathrm{ABa}$ & 1899.6 & A a & 1520.5 & $\mathrm{~B} \mathrm{~b}$ \\
\hline $\mathrm{PT}+\mathrm{EX}+\mathrm{FX}$ & 1578.3 & A b & 1852.8 & A a & 1913.2 & A a & 1835.5 & A a \\
\hline \multicolumn{3}{|c|}{---------------------CV (\%) Season:------------------ } & \multicolumn{6}{|c|}{ 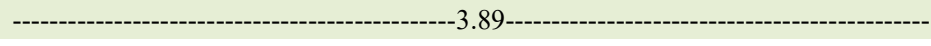 } \\
\hline \multicolumn{3}{|c|}{------------------CV (\%) Formulation:---------------- } & \multicolumn{6}{|c|}{ 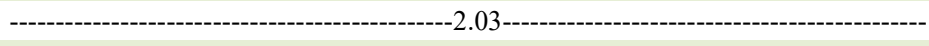 } \\
\hline \multicolumn{3}{|c|}{ 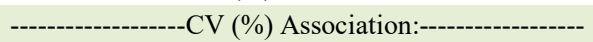 } & ----------. & 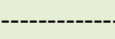 & - & 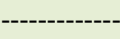 & & \\
\hline
\end{tabular}

Key: $\mathrm{H}_{2} \mathrm{O}$ : water; $\mathrm{AZ}+\mathrm{CP}$ : azoxystrobin + cyproconazole; $\mathrm{PC}+\mathrm{CP}$ : picoxystrobin + cyproconazole; $\mathrm{PT}+\mathrm{EX}+\mathrm{FX}:$ pyraclostrobin + epoxiconazole + fluxapyroxad; $\mathrm{H}_{2} \mathrm{O}_{2}$ : hydrogen peroxide; CLTN: chlorothalonil; MZB: mancozeb. Means followed by the same uppercase letter in columns and lowercase letter in rows do not differ significantly, as determined using the Tukey test $(\mathrm{P}<0.01)$. Data were transformed using $\sqrt{ } x$.

in photosynthetic rate and expression of genes in response to hydric stress in soybean (ISHIBASHI et al., 2017); induction of corn root growth and antioxidant activity (AHMAD et al., 2012); and induction of lignin deposition via activation of the jasmonic acid signaling pathway, thereby increasing resistance to penetration by Phytophthora infestans in potato plants (SOROKAN et al., 2017). Accordingly, we suspected that some or all of these effects may go some way to explaining the increase in the control of Asian rust in soybean and the increase in yield obtained with the addition of $\mathrm{H}_{2} \mathrm{O}_{2}$.

In addition to the indirect effects obtained via changes in plant physiology, the observed increase in the control of ASR by combining $\mathrm{H}_{2} \mathrm{O}_{2}$ with fungicides can also be attributed to its direct action via disruption at multiple sites in fungal cells. It has the effect of reducing the population of isolates resistant to site-specific fungicides, thereby positively influencing the control of the fungus (MATTOS et al., 2003). In a further association model, DELGADO et al. (2012) combined increased temperature and $\mathrm{H}_{2} \mathrm{O}_{2}$ and reported lower survival in two heatresistant fungal species (Neosartorya fischeri and Paecilomyces variotii) at higher concentrations of $\mathrm{H}_{2} \mathrm{O}_{2}$ (at the same temperature). As described for the association with fungicides, the combination with
$\mathrm{H}_{2} \mathrm{O}_{2}$ resulted in increased disease control compared with the traditional management model.

In general, with respect to all variables studied, we detected a positive response in treatments in which $\mathrm{H}_{2} \mathrm{O}_{2}$ was added to commercial formulations containing DMI + QoI fungicides (azoxystrobin + cyproconazole and picoxystrobin + cyproconazole), with reductions in the severity of soybean rust and an enhancement effect on soybean crop yield.

\section{CONCLUSION}

The addition of $\mathrm{H}_{2} \mathrm{O}_{2}$ to applied commercial formulations of fungicides azoxystrobin + cyproconazole and picoxystrobin + cyproconazole enhanced the control of Asian rust, thereby leading to a reduction in defoliation and increased soybean yields.

The addition of $\mathrm{H}_{2} \mathrm{O}_{2}$ to commercial formulations containing QoIs + DMIs can serve as an alternative strategy to the use of mancozeb and chlorothalonil with the aim of improving the performance of mixed commercial fungicide formulations. However, $\mathrm{H}_{2} \mathrm{O}_{2}$ applied alone was found to be ineffective in the management of $P$. pachyrhizi, and therefore, it is recommended that $\mathrm{H}_{2} \mathrm{O}_{2}$ be applied in combination with site-specific fungicides.

Ciência Rural, v.52, n.3, 2022. 


\section{ACKNOWLEDGEMENTS}

Special thanks to Conselho Nacional de Desenvolvimento Científico e Tecnológico (CNPq) for supporting a scholarship to Paulo Henrique Nascimento de Souza.

\section{DECLARATION OF CONFLICT OF INTEREST}

The authors declare that there are no conflicts of interest regarding the publication of this article.

\section{AUTHOR CONTRIBUTIONS}

The authors contributed equally to the manuscript.

\section{REFERENCES}

AHMAD, I. et al. Effect of seed priming with ascorbic acid, salicylic acid and hydrogen peroxide on emergence, vigor and antioxidant activities of maize. African Journal of Biotechnology, v.11, n.5, p.1127-1137, 2012. Available from: <https://doi.org/10.5897/ AJB11.2266>. Accessed: Jul. 29, 2020. doi: 10.5897/AJB11.2266.

ALVES, V. M.; JULIATTI, F. C. Fungicides in the management of soybean rust, physiological processes and crop productivity. Summa Phytopathologica, v.44, n.3, p.245-251, 2018. Available from: $\quad<$ https://www.scielo.br/j/sp/a/ckbBDsCTckjNBcsMWr k9tjv/?lang=pt $>$. Accessed: Jan. 28, 2020. doi: 10.1590/0100$5405 / 167203$

AVER'YANOV, A. A. et al. Suppression of early stages of fungus development by hydrogen peroxide at low concentrations. Plant Pathology Journal, v.6, n.3, p.242-247, 2007. Available from: $<$ https://scialert.net/abstract/?doi=ppj.2007.242.247>. Accessed: Jan. 05, 2020. doi: 10.3923/ppj.2007.242.247.

BALARDIN, R. S. et al. Mancozebe: Muito além de um fungicida. Bookman: Porto Alegre, 2017.

CAMPBELL, C. L.; MADDEN, L. V. Introduction to plant disease epidemiology. New York NY. John Wiley \& Sons, 1990.

CARVALHO, F. E. L. et al. Salt stress acclimation in Rice plants induced by $\mathrm{H}_{2} \mathrm{O}_{2}$ pretreatment. Revista Brasileira de Engenharia Agrícola e Ambiental, Campina Grande, v.15, n.4, p.416-423, 2011. Available from: $<$ https://www.scielo.br/j/rbeaa/a/TcyvWmL CW6fjRhwPRFnJdBb/?lang=pt\&format $=$ pdf $>$. Accessed: Jul. 28, 2020. doi: $10.1590 /$ S1415-43662011000400014.

DELGADO, D. A. et al.Inactivation of Neosartorya fischeri and Paecilomyces variotii on paperboard packaging material by hydrogen peroxide and heat. Food Control. v. 23, n. 1, p.165-170, 2012. Available from: <https://www.sciencedirect.com/science/ article/pii/S0956713511002763?via\%3Dihub>. Accessed: Mar. 04, 2021. doi: 10.1016/j.foodcont.2011.07.004.

FEHR, W. R.; CAVINESS, C. E. Stages of soybean development. Ames, Yowa: Yowa State University of Science and Technology, Cooperative Extension Service, 1977. 11 p. (Special Report, n. 80)

FRAC. Informação sobre carboxamidas em ferrugem da soja. Jaguariuna: Frac Brasil, 2017, 3p. (Informativo 01/2017).
GODOY, C. V. et al. Scale for assessment of soybean rust severity. Fitopatologia Brasileira, Brasília, v.31, n.1, p.63-68, 2006. Available from: <https://www.scielo.br/j/fb/a/7zsWfRPH6xXNG HjsS4ZSNwN/?lang=en\&format=pdf $>$. Accessed: Feb. 05, 2020. doi: 10.1590/S0100-41582006000100011.

HIRANO, M. et al. Validation of diagrammatic scale for estimating defoliation caused by the Asian rust in soybeans. Summa Phytopathologica, Botucatu, v.36, n.3, p.248-250, 2010. Available from: $\quad<$ https://www.scielo.br/j/sp/a/crkDtztZRx8RBjyxVYPP wSL/?lang=pt $>$. Accessed: Dec. 10, 2019. doi: 10.1590/S010054052010000300012 .

ISHIBASHI, Y. et al. The interrelationship between abscisic acid and reactive oxygen species plays a key role in barley seed dormancy and germination. Front Plant Science, v.21, n.8, 2017. Available from: <https://pubmed.ncbi.nlm.nih.gov/28377774/>. Accessed: Jul. 25, 2020. doi: 10.3389/fpls.2017.00275.

ISHII, H.; HOLLOMON, D. W. Fungi resistance in plant pathogens: principles and guide to practical management. Springer: Tokyo, 2015.

KANETIS, L. et al. Optimizing efficacy of new postharvest fungicides and evaluation of sanitizing agents for managing citrus green mold. Plant Disease, v.92, n.2, 2008. Available from: $<$ https://apsjournals.apsnet.org/doi/10.1094/PDIS-92-2-0261>. Accessed: Aug. 02, 2020. doi: 10.1094/PDIS-92-2-0261.

KEINATH, A. P.; DUBOSE, V. Disinfectant treatments that reduce transmission of Stagonosporopsis citrulli during cucurbit grafting. Plant Disease, v.101, n.11, p.1895-1902, 2017. Available from: $<$ https:// apsjournals.apsnet.org/doi/full/10.1094/PDIS-03-17-0451-RE>. Accessed: Dec. 23, 2019. doi: 10.1094/PDIS-03-17-0451-RE.

KLOSOWSKI, A. C. et al. Detection of the F129L mutation in the cytochrome b gene in Phakopsora pachyrhizi. Pest Management Science, v.72, p.1211-1215, 2016. Available from: $<$ https://www. ncbi.nlm.nih.gov/pubmed/26296393 >. Accessed: Feb. 02, 2020. doi: $10.1002 /$ ps.4099.

LINLEY, E. et al. Use of hydrogen peroxide as a biocide: new consideration of it mechanisms of biocidal action. Journal of Antimicrobial Chemotherapy, v.67, n.7, p.1589-1596, 2012. Available from: <https://pubmed.ncbi.nlm.nih.gov/22532463/>. Accessed: Jul. 27, 2020. doi: 10.1093/jac/d ks129.

MATTOS, I. L. et al. Peróxido de hidrogênio: importância e determinação. Química Nova, São Paulo, v.26, n.3, p.373-380, 2003. Available from: <http://quimicanova.sbq.org.br/detalhe artigo.asp?id=4637>. Accessed: Feb. 04, 2020. doi: 10.1590/ S0100-40422003000300015.

REIS, E. M. et al. Comparison of the efficacy of QoI fungicides, alone or in mixture with triazoles, in asian soybean rust control, 2016/17 growing season. Summa Phytopathologica, Botucatu, v.45, n.1, p.28-32, 2019. Available from: <https://www.scielo.br/j/ sp/a/mtbz4pFTdkvrT3sxqDHyyyf/?lang=en $>$. Accessed: Jan. 30, 2020. doi: 10.1590/0100-5405/190157.

SCHMITZ, H. K. et al. Sensitivity of Phakopsora pachyrhizi towards quinone-outside-inhibitors and demethylation-inhibitors, and corresponding resistance mechanisms. Pest Management Science, v.7, n.1, p.378-88, 2014. Available from: <https:// onlinelibrary.wiley.com/doi/abs/10.1002/ps.3562>. Accessed: Feb. 05, 2020. doi: $10.1002 /$ ps.3562. 
SHAPIRO, S. S.; WILK, M. B. An analysis of variance test for normality (complete sample). Biometrika, Great Britain, v.52, n.3, p.591-611, 1965. Available from: <https://www. jstor.org/stable/2333709>. Accessed: Dec. 02, 2019. doi: $10.2307 / 2333709$.

SOROKAN, A. V. et al. Anionic peroxidase mediated oxidative burst requirement for jasmonic acid dependent Solanum tuberosum defence against Phytophthora infestans. Plant Pathology, v.67, n.2, p.349-357, 2017. Available from: <https://bsppjournals.onlinelibrary.wiley.com/doi/ full/10.1111/ppa.12743>. Accessed: Feb. 18, 2020. doi: 10.1111/ ppa. 12743.

SOSNOWSKI, M. R. et al. Evaluating treatments and spray application for the protection of grapevine pruning wounds from infection by Eutypa lata. Plant Disease. v.97, n.12, p.1599-1604 2013. Available from: $<$ https://apsjournals.apsnet.org/doi/10.1094/ PDIS-02-13-0201-RE>. Accessed: Dec. 20, 2019. doi: 10.1094/ PDIS-02-13-0201-RE.
VAN WYK, S. J. P. et al. Sanitation of a South African forestry nursery contaminated with Fusarium circinatum using hydrogen peroxide at specific oxidation reduction potentials. Plant Disease, v.96, n.6, p.875-880, 2012. Available from: <https://apsjournals. apsnet.org /doi/10.1094/PDIS-05-11-0432>. Accessed: Jan. 18, 2020. doi: 10.1094/PDIS-05-11-0432.

YOKOYAMA, A. H. et al. Leaf área índex and SPAD during the soybean development cycle at different plant densities and their relation to grain yield. Revista de Ciências Agroveterinária, Lages, v.17, n.4, p.531-538, 2018. Available from: <https:// revistas.udesc.br/index.php/agroveterinaria/article/view/9126 >. Accessed: Feb. 07, 2020. doi: 10.5965/223811711732018531.

ZUNTINI, B. et al. Effect of adding fungicide to mixtures of triazoles and strobilurins in the control of downy mildew and asian soybean rust. Pesquisa Agropecuária Tropical, Goiania, v.49, n.1, p.1-9, 2019. Available from: <https://www.scielo.br/j/ pat/a/W9Wwk639HMLJxYyWs6tYXJh/?format=pdf\&lang=en>. Accessed: Feb. 01, 2020. doi: 10.1590/1983-40632019v4953688. 